\title{
Production and identification of haploid dwarf male sterile wheat plants induced by corn inducer
}

Wei Zhang ${ }^{\dagger}$, Ke Wang $^{\dagger}$, Zhi-Shan Lin ${ }^{\dagger}$, Li-Pu Du, Hai-Li Ma, Le-Le Xiao and Xing-Guo Ye

\begin{abstract}
Background: Using the cross of wheat and maize is a very useful way to produce wheat haploid plants by chromosome elimination. Dwarf male sterile wheat (DMSW) and corn inducer are potential important germplasm for wheat breeding by recurrent selection and doubled haploid strategies. There is no report yet to achieve the haploid plants from DMSW induced by maize inbred line and especially the corn inducer.

Results: Haploid plants of DMSW were successfully obtained in this study induced by both maize pollens of inducer line and normal inbred line. The efficiencies for wheat embryos formation and plantlets production induced by the two corn lines had no significant difference. All the eleven haploid wheat plants derived from the male sterile material were identified by botanic appearance, cytology, cytogenetics, and molecular markers. They were all haploid based on their guard cell length of $42.78-42.90 \mu \mathrm{m}$ compared with the diploid control of $71.52 \mu \mathrm{m}$, and their chromosome number of 21 compared with the diploid control of 42. In addition, according to anthers, plant height, and molecular markers, the haploid plants were divided into two types. Eight of them showed dwarf, having no anthers, and the special band of $R h+10$, and the other three plants displayed normal plant height, having anthers, and not containing the special band of Rht10, indicating that they were originated from the MS2/Rht10 and $m s 2 / r h t 10$ female gametes, respectively.
\end{abstract}

Conclusions: MS2/Rht10 haploid plants were successfully obtained in this study by using corn inducer and inbred line, and will be employed as candidate materials for the potential cloning of MS2 dominant male gene.

Keywords: Corn inducer; Dwarf male sterile wheat; Intergeneric cross; Ms2 haploid plant

\section{Background}

Wheat is an economic valuable crop species worldwide, and its continual genetic improvement on yield, disease resistance, processing quality, and abiotic stress tolerance is closely associated with food security production for human being (Shewry 2009; Tester and Langridge 2010; He et al. 2011). In wheat breeding program germplasm takes an essential role for the development of new varieties. Wheat germplasm with various distinguished characteristics can be identified in natural population or bred by commercial and wild cross and mutation

\footnotetext{
*Correspondence: yexingguo@caas.cn

${ }^{\dagger}$ Equal contributors

National Key Facility for Crop Gene Resources and Genetic Improvement, Key Laboratory of Biology and Genetic Improvement of Triticeae Crops of Ministry of Agriculture, Institute of Crop Sciences, Chinese Academy of Agricultural Sciences, Beijing 100081, China
}

(He et al. 2011; von Well and Ncala 2013). Of them, male sterile materials are beneficial to hybrid applications and recurrent selection of wheat (Zhai and Liu 2009). Up to date, three key male sterile genes have been found in wheat. A recessive male sterile gene, $m s 1$, was found to be located on chromosome 4A (Driscooll 1978), but this gene was not convenient to be employed in wheat breeding procedure. A dominant male sterile gene, MS3, was obtained from the nuclear-cytoplasm hybrid between wheat and Aegilops squarrosa after treatment by ethyl methane sulfonate (EMS) (Maan et al. 1987; Qi and Gill 2001).

An important wheat male sterile mutant was found in 1972 by Gao (1987). Genetic analysis demonstrated that its male sterility was controlled by a single dominant gene Tal (Deng and Gao 1980, 1982), which was renamed as Ms2 later (Cao et al. 2009; Zhai and Liu 2009). Ms2 exists in wheat plants always in heterozygous status of $M s 2 m s 2$, 
and inherits itself by accepting the pollens of normal wheat varieties with $m s 2 m s 2$ genotype at this locus (Deng and Gao 1980, 1982, 1987; Gao 1987). Ms2ms2 plants have no anthers completely while their pistils are developed normally, and their next generation always produced sterile plants by half with genotype $M s 2 m s 2$ and fertile plants by another half with genotype ms2ms2 (Deng and Gao 1980, 1982, 1987; Zhai and Liu 2009). By using telosomic mapping and genetic analysis approaches, this gene was located on the short arm of chromosome 4D, and $31.16 \mathrm{cM}$ away from the centromere (Liu and Deng 1986a, b). To identify the $M s 2$ gene and distinguish male sterile plants in early stage, a dwarf male sterile wheat (DMSW) was further developed by crossing the male sterile Chinese Spring with Aibian 1 carrying the dwarfing gene Rht10 (Rht-D1c) and backcrossing the dwarfing $F_{1}$ male sterile plants with normal Chinese Spring, in which $M s 2$ gene was linked closely with Rht10 gene with a genetic distance of $0.12 \mathrm{cM}$ (Liu and Yang 1991; Zhai and Liu 2009). Since then, the dwarf male sterile wheat has been efficiently applied in wheat breeding for population improvement through recurrent selection and genetic variation expansion through easily cross-making (Liu et al. 2002), and a number of new wheat varieties have been developed by using the special material (Zhai and Liu 2009). However, Ms2 has not been successful cloned and a perfect direct molecular marker for it has not been developed yet. The main problem is that the male sterile gene always exists in heterozygous state and the DNA samples are mixed with $m s 2$ from male gametes in this kind of dwarf male sterile wheat plants. Therefore, it is necessary to obtain haploid or double haploid male sterile plants derived from the $M s 2$ female gametes.

Cao et al. (2009) found that WMC617 marker was closely linked to the male sterile $M s 2$ gene and the dwarfing Rht10 gene among 48 pairs of SSR primers by bulked segregation analysis, and further mapped the two genes at the distal position of chromosome 4DS. Li et al. (2012) revealed that the $R h t 10$ allele contained in DMSW was generated through a tandem segmental duplication (TSD) of a region more than $1 \mathrm{Mb}$ carrying Rht2 (Rht-D1b) gene, resulting in two copies of $R h t 2$, namely that $R h t 10$ was completely identical to $R h t 2$ in sequence. Further, they analyzed the segregation population containing Rht10 gene by using $R h t 2$ gene-specific primers. It is implied that $R h t 10$ in DMSW also can be detected by the perfect PCR-based marker pairs of DF-MR2 developed by Ellis et al. (2002).

Wild cross of wheat and maize is the ideal way to induce female gametes originating wheat haploid plants (Laurie and Bennett 1988a). This technique has now been widely used in the production of wheat haploid plants (Laurie and Reymondies 1991; Sun et al. 1992; Chen et al. 1996a, b). Sun et al. (1999) firstly achieved the $M s 2$ haploid plants by crossing the male sterile wheat with normal inbred maize line, and identified the haploid by cytogenetics.
Current study is trying to obtain $M s 2 / R h t 10$ haploids by using the dwarf male sterile wheat and corn inducer, and to compare the induction efficiency of corn inducer and normal inbred corn line. The obtained haploids will be identified by botanical traits, cytology, and molecular marker. Results generated in this study will be useful for marker development and isolation of $M s 2$ gene, and for the production of wheat haploid plants using corn inducer.

\section{Methods}

\section{Plant materials}

Dwarf male sterile wheat (DMSW) line DS987 was kindly provided by Prof. Binghua Liu at the Institute of Crop Sciences (ICS), Chinese Academy of Agricultural Sciences (CAAS). Chinese Spring (CS) was demanded from the National Crop Germplasm Preservation Center at the ICS, CAAS. The pollens of corn inducer CI011-1 and Zheng58 were collected from the greenhouse of National Key Facility for Crop Gene Resources and Genetic Improvement. CI011-1 was developed by Biotechnology Research Institute of CAAS using a corn inducer, HZI1, as one parent and frequently employed for the production of maize haploid plants by the scientists in our institute (ICS, CAAS). Zheng58 was developed by Henan Xingyang Feilong Seed Limited Company of China and normally used for the induction of wheat haploid plants at ICS, CAAS.

\section{Crossing and hybrid embryos rescue of DMSW and corn inducer}

The seeds of DMSW line DS987 were planted in the greenhouse with a photoperiod of $14 \mathrm{~h}$ light $/ 10 \mathrm{~h}$ darkness and a temperature regime of $25^{\circ} \mathrm{C}$ day $/ 15^{\circ} \mathrm{C}$ night. Once the heads of the male sterile plants were just completed out of the sheaths of the flag leaves, the spikes were prepared by removing the up and down spikelets and the middle florets of each remaining spikelet, and cutting the top part of the lemmas of each floret with scissors. Then, the prepared spikes were bagged with sulfuric acid paper. Three days later, the bagged spikes were pollinated with the pollens of the two maize lines by pouring from the top of the bags with hand shaking. On the next 2 days, the pollinated spikes were treated with 2,4-dichlorophenoxyacetic acid (2,4-D) $100 \mathrm{mg} \mathrm{L}^{-1}$ containing solution for 2 times (Chen et al. 1996a; Chen et al. 1996b). 14-15 days post pollination, the immature grains were collected and sterilized with $70 \%$ ethanol for $1 \mathrm{~min}$, immersed in $20 \%$ bleach for $15 \mathrm{~min}$ and rinsed with sterile distilled water for five times inside laminar flow bench. The immature embryos were isolated with inoculating needle under anatomical lens and cultured in axial side up on germination medium ( $\mathrm{pH}$ 6.0) containing 1/2 Murashige and Skoog (1962) (MS) basal salts, 2.0\% sucrose, B5 vitamins, and $2.4 \mathrm{~g} \mathrm{~L}^{-1}$ phytagel at conditions of $25 \pm 1^{\circ} \mathrm{C}, 16 \mathrm{~h}$ 
photoperiod, $400 \mu \mathrm{mol} \mathrm{m}{ }^{-2} \mathrm{~s}^{-1}$ photosynthetic photon flux density and $45 \%$ relative humidity for 4 wk to obtain healthy haploid plantlets (Chen et al. 1996b, 2013). Finally, the plantlets were transplanted in soil in natural environment condition for further investigation. Test of percent hypothesis was used to evaluate the difference of corn inducer and normal inbred lines on inducing wheat haploid plants.

\section{Root tips preparation and chromosome observation}

Cytological analyses followed the procedures described by Lin et al. (2002). Roots excised from the rescue plantlets and the DMSW control plants were treated in ice-water for about $24 \mathrm{~h}$, fixed in ethyl alcohol and acetic acid mixture ( $3: 1$ ) for $24 \mathrm{~h}$, and then transferred to $95 \%$ ethyl alcohol and stored at $-20^{\circ} \mathrm{C}$ until use. The fixed materials were hydrolysed in $1 \mathrm{~N} \mathrm{HCl}$ at $60^{\circ} \mathrm{C}$ for $14 \mathrm{~min}$, and then stained with Schiff's reagent. Squashes of the relevant tissues were made in a drop of $1 \%$ acetocarmine on slides. Chromosome number was counted with microscope.

\section{DNA extraction and PCR amplification}

Wheat leaves were collected from the plants of generated haploids between DMSW and corn inducer, DMSW DS987, and CS at booting stage, and their genomic DNA were extracted using modified cetyltrimethylammonium bromide (CTAB) method [3\% (w/v) CTAB, $1.4 \mathrm{M} \mathrm{NaCl}$, $20 \mathrm{mM}$ ethylenediaminetetraacetic acid (EDTA), $0.1 \mathrm{M}$ Tris $\mathrm{HCl}, \mathrm{pH} 8.0,2 \%(\mathrm{w} / \mathrm{v})$ polyvinylpolypyrrolidone and $0.2 \%$ (v/v) 2-mercaptoethanol] (Mahanil et al. 2007). The DNA pellet was dissolved in sterile water.

A pair of PCR primers specific to Rht2 gene (Accession number in Genbank: JF930281) of 5' -CGCGCAATTATT GGCCAGAGATAG-3' and 5'-CCCCATGGCCATCTCG AGCTGCTA-3' named as DF-MR2 (Ellis et al. 2002) were used to identify whether the freshly produced haploid wheat plants between DMSW and corn inducer contain $R h t 2$ gene or $M s 2$ gene. PCR reaction was performed in a final volume of $20 \mu \mathrm{L}$ consisting of $100 \mathrm{ng}$ of genomic DNA, $10 \mathrm{uL}$ of $2 \times$ Taq MasterMix (CwBio, China), $3 \mu \mathrm{M}$ of each primer and $7.4 \mu \mathrm{L}$ of $\mathrm{ddH}_{2} \mathrm{O}$. Amplification process consists of $94^{\circ} \mathrm{C}$ for $5 \mathrm{~min}$, seven "touchdown" cycles of $94^{\circ} \mathrm{C}$ for $30 \mathrm{~s}, 65^{\circ} \mathrm{C}$ for $30 \mathrm{~s}, 72^{\circ} \mathrm{C}$ for $1 \mathrm{~min} 20 \mathrm{~s}$ with a $1^{\circ} \mathrm{C}$ drop in annealing temperature at each cycle, followed by 34 cycles of $94^{\circ} \mathrm{C}$ for $15 \mathrm{~s}, 58^{\circ} \mathrm{C}$ for $15 \mathrm{~s}, 72^{\circ} \mathrm{C}$ for $50 \mathrm{~s}$, and one cycle of $72^{\circ} \mathrm{C}$ for $10 \mathrm{~min}$. PCR products were separated on $2.0 \%$ agarose gel, and observed under UV light.

Determination of the length of guard cells on wheat leaves Leaf pieces of $2 \mathrm{~cm}$ in length were collected from each plant at jointing stage, and put on the center of a glass slide upward of the leaf abaxial epidermis. The samples were fixed with left forefinger and the mesophyll tissues were scraped off carefully by a scalpel with a little bit water until the thin achromatic epicuticula left. The stoma guard cells on the epidermis were observed and measured under an optical microscope incorporated with daily mirror micrometer (Wang et al. 1989; Du et al. 1996). Each plant was measured by ten guard cells for statistics, and the data was statistically analyzed by SPPS13.0 Software (SPSS Chicaco, USA) for significant difference and standard deviation.

\section{Results}

Obtaining of haploid dwarf male sterile wheat plants assisted with the pollen of corn inducer

The prepared and bagged spikes of dwarf male sterile wheat line DS987 three days ago were pollinated with freshly collected pollens of corn inducer and normal inbred line. After pollination and 2,4-D treatment for 15 days, in total twenty-eight and eleven developing immature embryos were obtained from the induction of corn inducer and normal inbred line, respectively, and inoculated on the rescue medium for further growing. Finally, eight healthy plantlets were initiated by the corn inducer, and three by the normal inbred line (Figure 1). Results suggested that the frequencies for the embryos formation and plantlets induction induced by the corn inducer line $(5.00 \%$ and $1.43 \%$, respectively) were slight higher than those by the normal inbred line $3.44 \%$ and $0.94 \%$, respectively), but the induction rate difference between the two maize lines for wheat embryos and

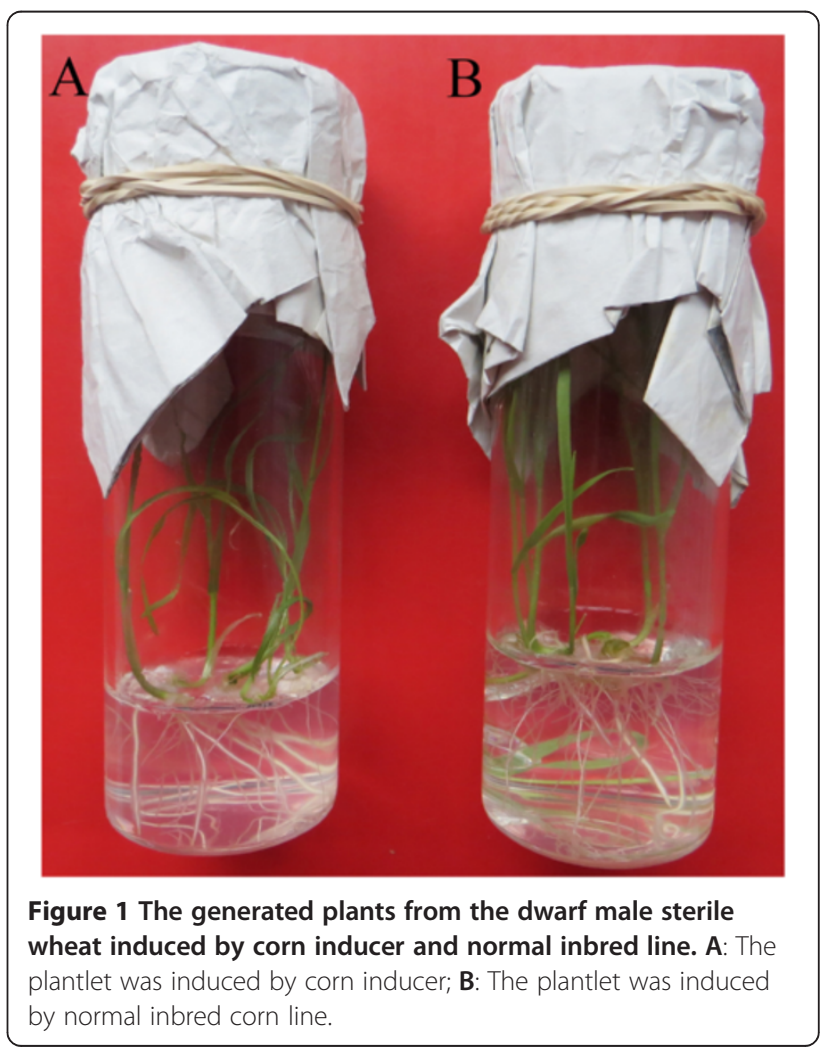


Table 1 Production of haploid dwarf male sterile wheat plants induced by corn inducer and normal inbred line

\begin{tabular}{cccccc}
\hline $\begin{array}{c}\text { Donors of } \\
\text { maize pollen }\end{array}$ & $\begin{array}{c}\text { Florets } \\
\text { pollinated }\end{array}$ & $\begin{array}{c}\text { Embryos } \\
\text { cultured }\end{array}$ & $\begin{array}{c}\text { Plantlets } \\
\text { obtained }\end{array}$ & $\begin{array}{c}\text { Embryos formation } \\
\text { rate* (\%) }\end{array}$ & $\begin{array}{c}\text { Plantlets induction } \\
\text { rate* }\end{array}$ \\
\hline Cl011-1 & 560 & 28 & 8 & 5.00 & 1.43 \\
Zheng58 & 320 & 11 & 3 & 3.44 & 0.94 \\
\hline
\end{tabular}

*The embryo formation rate was calculated through the number of cultured embryos divided by the number of pollinated florets. The plantlet induction rate was calculated via the number of obtained plants divided by the number of pollinated florets. The rates difference between the two maize lines for wheat embryos formation and plantlets induction were not significant $(P>0.05)$ by percent hypothesis test.

plantlets was not significant $(\mathrm{P}>0.05)$ according to percent hypothesis test (Table 1).

Identifying of the haploid dwarf male sterile wheat plants by cytology and botanical appearance

The obtained eleven plants from the wild cross were examined for chromosome constitution before transplanted into soil. Twenty-one chromosomes were observed in all the rescued plants (Figure 2A), while the number was forty-two in the plants of dwarf male sterile wheat line DS987 (Figure 2B). Normally, the length of stoma guard cells on abaxial epidermis of leaves is used to primarily identify the ploidy of the plants from another culture. The size of $61.0-63.0 \mu \mathrm{m}$ was regarded to the boundary of haploid and diploid wheat plants (Wang et al. 1989; $\mathrm{Du}$ et al. 1996). Thereby, the generated plants were measured for the length of guard cells on leaves at jointing stage. The average length of the guard cells was $42.90 \pm 2.84 \mu \mathrm{m}$ (varied from $40.80 \mu \mathrm{m}$ to $46.80 \mu \mathrm{m}$ ) and $42.78 \pm 1.83 \mu \mathrm{m}$ (varied from $40.80 \mu \mathrm{m}$ to $45.10 \mu \mathrm{m}$ ) for the short and high rescued plants, respectively (Figure 3A), which were not different significantly between the cells and plants. While, the corresponding value was $71.52 \pm 4.62 \mu \mathrm{m}$ (varied from $67.20 \mu \mathrm{m}$ to $79.20 \mu \mathrm{m}$ ) for DS987 plants (Figure 3B). Above results demonstrated that all the generated plants from the distant cross were in haploid status. Among the eleven haploid plants, three of them were about $75 \mathrm{~cm}$ in plant height (Figure 4A) and had three anthers in each floret (Figure 5A), appearing normal plant height and fertile botanical traits. And the other eight haploid plants were $30 \mathrm{~cm}$ around in plant height (Figure 4B) and had no anthers in the florets (Figure 5B), showing dwarfing and male sterile characteristics. We believe that the haploid plants with normal height and anthers were developed from $m s 2 / r h t 10$ female gametes, and the plants showing dwarfing and no anthers were originated from MS2/Rht10 female gametes. Once induced by maize pollens, the two types of female gametes all can develop into embryos.

Identifying of the haploid dwarf male sterile wheat plants by molecular marker

Ellis et al. (2002) developed a perfect PCR-based marker pairs DF-MR2 to detect Rht2 gene. Therefore, all the generated haploid plants obtained in this study were detected by the molecular marker for Rht10 and Ms 2 genes. Eight of the eleven plants amplified the specific band to Rht10 or $M s 2$, and the other three plants didn't amplify the specific band (Figure 6). The identification results of the haploid plants by botanical traits and molecular markers were matched in with each other, further confirming that the two groups of plants were originated from the MS2/Rht10 and $m s 2 / r h t 10$ female gametes, respectively.

\section{Discussion}

In the intergeneric cross between wheat and maize, genotypes of the both generas exert some influences on
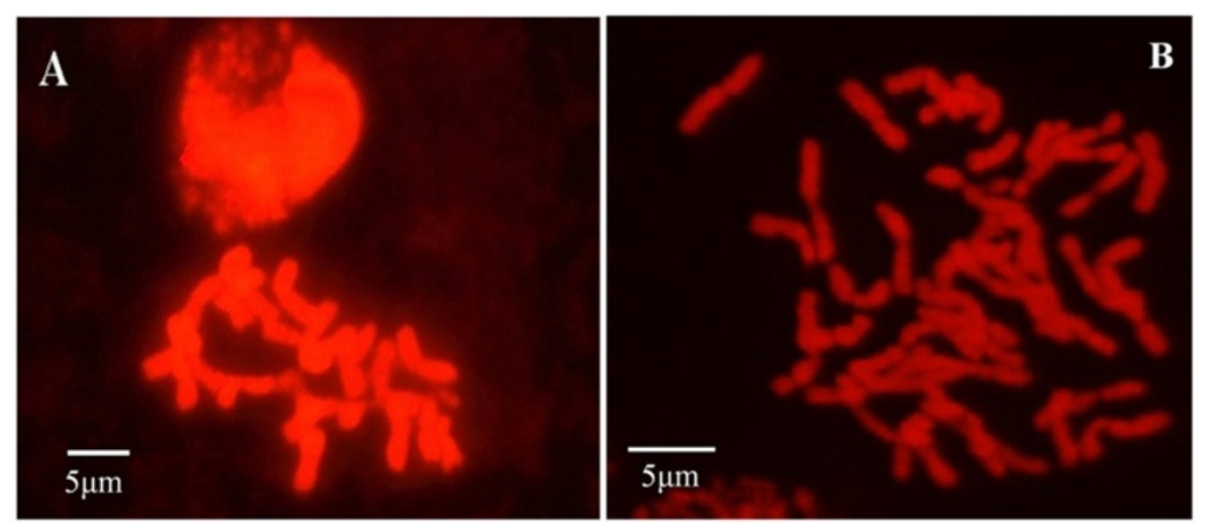

Figure 2 Chromosome constitution of the rescued plants derived from the dwarf male sterile wheat induced by maize pollens and control diploid plants. A: The rescued haploid plants contained 21 chromosomes; B: DS987 control plants contained 42 chromosomes. 

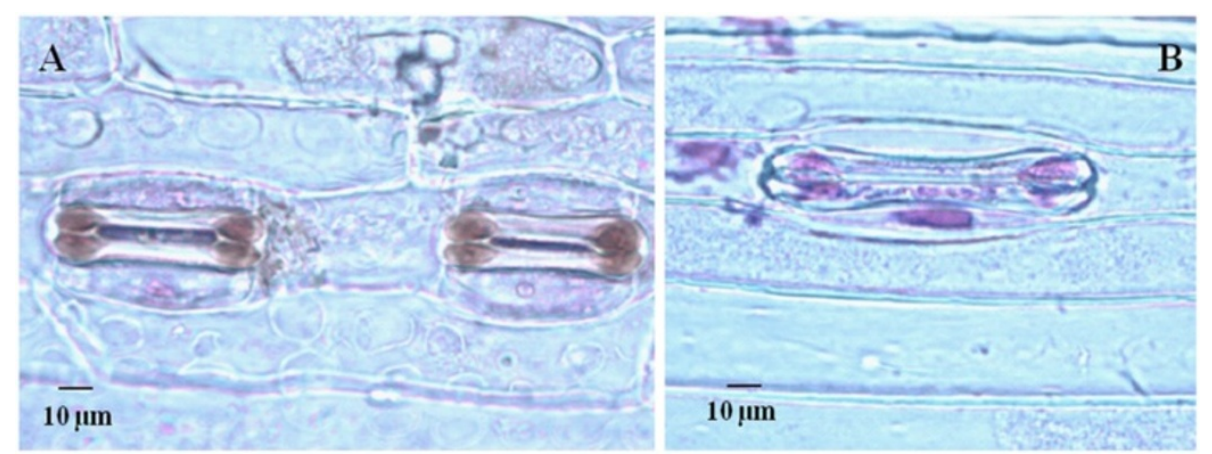

Figure 3 Leaf guard cells of the rescued plants derived from the dwarf male sterile wheat induced by maize pollens and control diploid plants. A: The rescued haploid plants had smaller guard cells; B: DS987 plants had larger guard cells.

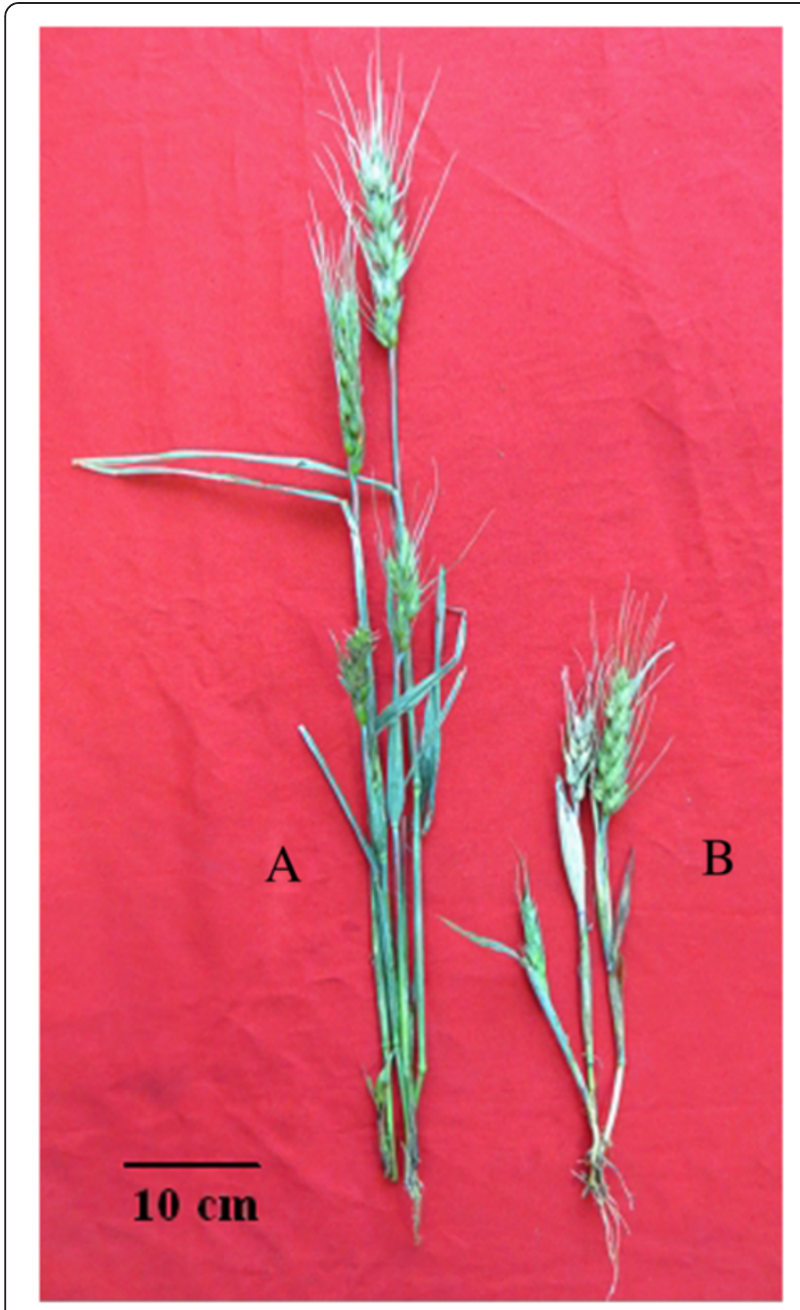

Figure 4 Height appearance of the haploid plants derived from the dwarf male sterile wheat induced by maize pollens. A: The ms2 haploid sterile plant showed normal height; $\mathbf{B}$ : The Ms2 haploid sterile plant showed short height. the formation of wheat haploid embryos. Using the same maize pollens to be pollinated, different wheat lines all could produce haploid embryos with various efficiencies (Inagaki and Tahir 1990; Cai et al. 2004). For example, Chen et al. (1998) reported the embryos formed rate was ranging from $18.5 \%$ to $29.1 \%$. The efficiencies were not only related to the growth habits of wheat varieties, but also to their origins (Laurie and Bennett 1988a; Suenaga and Nakajima 1989; Inagaki and Tahir 1990) and environmental conditions (Chen et al. 2013). However, it was demonstrated that the $K r$ gene in wheat background had no effect on the crossability of wheat and maize (Laurie and Bennett 1988b). On the other hand, a wheat line also could generate haploid embryos when pollinated with different maize genotypes, and sweet corn was better than waxy corn and normal corn in the induction efficiency of wheat haploid embryos (Suenaga and Nakajima 1989; Wang 1998; Cai et al. 2004).

Coe (1959) identified a corn inducer, Stock6, that induced parthenogernesis of maize by a higher frequency. Since then, a lot of improved corn inducers have been developed using Stock6 as parent by hybrid technique, such as WS14, Krasnodar Markers, MH1, M741H, ZMS, HZI1 (Lashermes and Beckert 1988; Chalyk 1994; Shatskaya et al. 1994; Eder and Chalyk 2002; Zhang et al. 2008; Elizabeth and William 2009). Through the use of corn inducer, plenty of haploid maize seeds can be easily obtained for its breeding (Shatskaya et al. 1994; Chang and Coe 2009; Elizabeth and William 2009; Chaikam 2012). For example, the frequency of maize haploids induced by MH1 was up to 8.0\% (Eder and Chalyk 2002). However, the effectiveness of corn inducer on the induction of haploid wheat plants has not been investigated yet. Haploid dwarf male sterile wheat plants were achieved for the first time in this study by using DMSW and corn inducer. Comparing with normal inbred maize line, corn inducer didn't show any increased induction effect on the formation of haploid wheat embryos (Table 1). It is inferred that the corn inducer cannot induce 


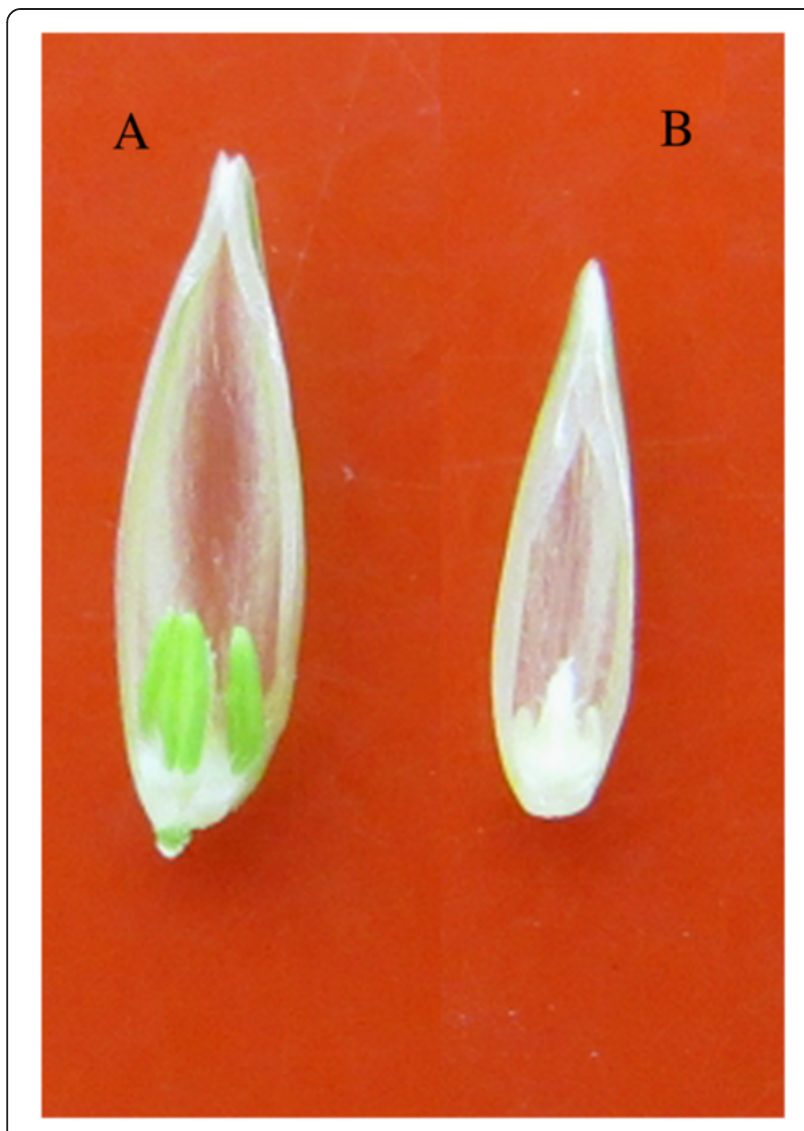

Figure 5 Fertile traits of the haploid plants derived from the dwarf male sterile wheat induced by maize pollens. A: The ms2 haploid sterile plants had anthers but no pollens; B: The Ms2 haploid sterile plants had no anthers.

haploid plants in wheat with a high rate as it does in maize. In addition, the frequencies for haploid wheat embryos formation and plantlets induction induced by either the corn inducer or the normal maize inbred line were very low in this study comparing with other studies by inbred maize lines or hybrid maize varieties (Cai et al. 2004; Chen et al. 2013), and it might be related to the used DMSW or maize lines and environmental conditions (Suenaga and Nakajima
1989; Inagaki and Tahir 1990; Wang 1998; Cai et al. 2004; Chen et al. 2013).

Sun et al. (1999) obtained homozygote of Taigu genic male sterile wheat plants by chromosome elimination induced by maize pollens, and identified the plants by chromosome constitution. They also tried to maintain the new precious material for long term through cryopreservation by vitrification because of its sterile feature. We successfully obtained haploid dwarf male sterile wheat plants by the similar strategy, and identified the plants combining by chromosome configuration (Figure 2), cytology (Figure 3), botanical traits (Figure 4, Figure 5), and molecular markers (Figure 6). It is proved that the male sterile wheat plants only carrying $M s 2$ gene can be easily achieved by the intergeneric cross of wheat and maize, and there is no need to keep the germplasm by cryopreservation. Especially, the Ms 2 haploid or homozygous plants can be conveniently recognized by the short plant height controlled by Rht10 dwarfing gene (Figure 4), and it can be used as an ideal material to further clone $M s 2$ genes in avoid of the interference of $m s 2$ in the diploid dwarf male sterile wheat. Next, we plan to obtain doubled haploid $M s 2$ wheat plants using this approach, and analyze the plants by transcriptomics strategies such as RNA-Seq and proteomics techniques such as mass spectrometry comparing with the doubled haploid $m s 2$ plants derived from the same DMSW material correspondingly for the screening of differentially expressed genes and proteins between the two kinds of plants. And then, the differentially expressed genes or proteins will be confirmed by searching the sequenced wheat genomics and functionally analyzed by genetic transformation for the possible isolation of candidate $M s 2$ gene.

\section{Conclusions}

Haploid dwarf male sterile male wheat plants were obtained in this study by using corn inducer and normal inbred maize line. The efficiencies for wheat haploid embryos formation and plantlets production induced by the two types of corn lines had no significant difference. The haploid plants were further identified by botanical traits,

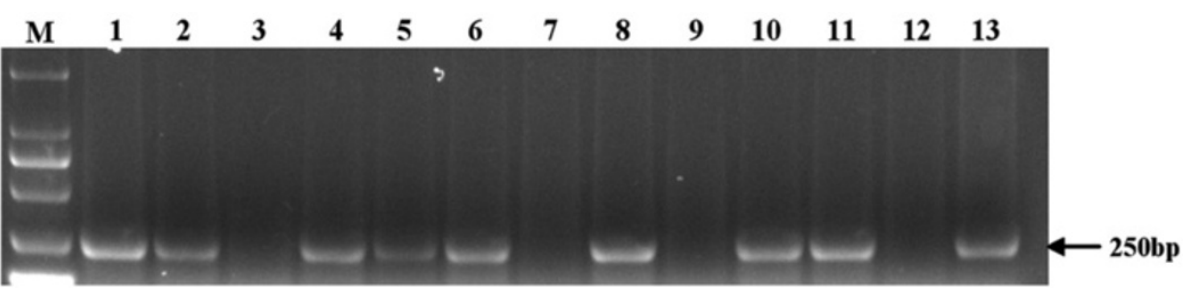

Figure 6 Detection of the rescued plants derived from the dwarf male sterile wheat induced by maize pollens and control diploid plants by molecular market of DF-MR2 for Rht2 gene or Ms2 gene. M: Marker ladder; 1-11: The rescued haploid plants from DMSW. The plants numbered with 1, 2, 4, 5, 6, 8, 10 and 11 showed the Rht2-specific band, meaning they were the haploid type of Ms2. The plants numbered with 3, 7, and 9 didn't have the Rht2-specific band, meaning they were the haploid type of ms2. 12: Chinese Spring, without the Rht2-specific band; 13: DS987, showing the Rht2-specific band. 
cytology, cytogenetics, and molecular marker, and will be potentially used for the cloning of $M S 2$ dominant male gene.

\section{Abbreviations}

2,4-D: 2,4-dichlorophenoxyacetic acid; CTAB: Cetyltrimethylammonium bromide; CS: Chinese Spring; DMSW: Dwarf male sterile wheat; EDTA: Ethylenediaminetetraacetic acid; EMS: Ethyl methane sulfonate; MS: Murashige and Skoog basal salt mixture; TSD: Tandem segmental duplication.

\section{Competing interests}

The authors declare that they have no competing interests of this research.

\section{Authors' contributions}

Y-XG and L-ZS designed the experiments together. Z-W, W-K and Y-XG made the intergeneric cross between wheat and maize. Z-W and D-LP determined the guard cells of the generated plants. X-LL, Z-W, W-K, and Y-XG investigated the botanic traits of the obtained haploid plants. M-HL and L-ZS finished the chromosome observation of the rescued and control plants. Z-W and W-K detected the plants by molecular marker. Y-XG and Z-W analyzed data, wrote and revised the manuscript. All authors read and approved the final manuscript.

\section{Acknowledgments}

We are grateful to Dr. Jiarui Li at Bayer Cropscience, USA, for critical revision of this manuscript. This research was financially supported in part by grant from the Ministry of Science and Technology of China (2011BAD35B03).

Received: 20 December 2013 Accepted: 17 February 2014

Published: 20 February 2014

\section{References}

Cai H, Ma CX, Zhou MP, Ma HX, Lu WZ (2004) Induction of wheat haploid through distant hybridization between wheat and maize. J Triticeae Crops 24(2):11-14 (in Chinese with English abstract)

Cao W, Somers DJ, Fedak G (2009) A molecular marker closely linked to the region of Rht-D1C and Ms2 genes in common wheat (Triticum aestivum). Genome 52:95-99

Chaikam V (2012) In vivo Maternal Haploid Induction in Maize. In: Prasanna BM, Chaikam V, George M (eds) Theory and Practice. Doubled Haploid Technology in Maize Breeding. CIMMYT, Mexico D.F, pp 9-13

Chalyk ST (1994) Properties of maternal haploid maize plants and potential application to maize breeding. Euphytica 79:13-18

Chang MT, Coe EH (2009) Doubled Haploids. In: Kriz AL, Larkins BA (eds) 63 Molecular Genetic Approaches to Maize Improvement. Biotechnology in Agriculture and Forestry. Springer, Heidelberg, pp 127-142

Chen XM, Lai GX, Chen X, Zhou JF, Liu JX, Sun FH (1996a) Difference of haploid production in crosses between different wheat F1 and maize. Acta Agron Sin 22:437-441 (in Chinese with English abstract)

Chen XM, Xu HJ, Zhou JF, Liu JX, Zhang HZ (1996b) A study on the increasing frequencies of plant production during embryo culture in crosses between wheat and maize. Sci Agric Sin 29(4):29-32 (in Chinese with English abstract)

Chen XM, Li XY, Chen X, Meng FH, Cui SL (1998) Effect of different crossing techniques on haploid production in wheat $\times$ maize crosses. Acta Agron Sin 24:743-746 (in Chinese with English abstract)

Chen XM, Wang FJ, Li SM, Zhang WX (2013) Stable production of wheat haploid and doubled haploid by wheat $\times$ maize cross. Acta Agron Sin 39:2247-2252 (in Chinese with English abstract)

Coe EH (1959) A line of maize with high haploid frequency. Am Naturalist 93:381-382

Deng JY, Gao ZL (1980) The use of a dominant male-sterile gene in wheat breeding. Acta Agron Sin 6(2):85-98 (in Chinese with English abstract)

Deng JY, Gao ZL (1982) Discovery and determination of a dominant male sterile gene and its importance in genetics and wheat breeding. Sci Sin (Ser B) 5:508-520

Deng JY, Gao ZL (1987) Determination of a Dominant Male Sterile Gene and its Prospect in Practice. In: Deng JY (ed) Taigu Genic Male-Sterile Wheat. China Agricultural Scientech Press, Beijing, pp 7-21 (in Chinese)

Driscooll CJ (1978) Induction and Use of the "Cornerst one" Male-Sterility in Wheat. Proc. 5th Int. Wheat Genet. Symp. India Society of Genetics and Plant Breeding, New Delhi, pp 499-502
Du LP, Xu HJ, Zhao LL, Zhang CX, Ye XG (1996) Identification of ploidy of wheat pollen plants using length of guard cell. Beijing Agric Sci 14(6):10-12 (in Chinese)

Eder J, Chalyk S (2002) In vivo haploid induction in maize. Theor Appl Genet 104:703-708

Elizabeth AL, William FT (2009) Modern Maize Breeding. In: Bennetzen JL, Hake S (eds) Genetics and Genomics, vol II, Maize Handbook. Springer Science Business Media LLC, Heidelberg, pp 141-160

Ellis MH, Spielmeyer W, Gale KR, Rebetzke GJ, Richards RA (2002) "Perfect" markers for the Rht-B1b and Rht-D1b dwarfing genes in wheat. Theor Appl Genet 105:1038-1042

Gao ZL (1987) The Discovery of the Taigu Genic Male Sterile Wheat. In: Deng JY (ed) Taigu Genic Male-Sterile Wheat. China Agricultural Scientech Press, Beijing, pp 5-6 (in Chinese)

He ZH, Xia XC, Chen XM, Zhuang QS (2011) Progress of wheat breeding in China and the future perspective. Acta Agron Sin 37(2):202-215 (in Chinese with English abstract)

Inagaki M, Tahir M (1990) Comparison of haploid production frequencies in wheat varieties crossed with Hordeum bulbosum L. and maize. Jpn J Breed 40(2):209-216

Lashermes P, Beckert M (1988) Genetic control of maternal haploidy in maize (Zea mays L.) and selection of haploid inducing lines. Theor Appl Genet 76(3):405-410

Laurie DA, Bennett MD (1988a) The production of haploid wheat plants from wheat $\times$ maize crosses. Theor Appl Genet 76(3):393-397

Laurie DA, Bennett MD (1988b) The effect of the crossability loci Kr1 and Kr2 on fertilization frequency in hexaploid wheat × maize crosses. Theor Appl Genet 76(3):393-397

Laurie DA, Reymondie S (1991) High frequency of fertilization and haploid seeding production in crosses between commercial hexaploid wheat varieties and maize. Plant Breed 106(3):182-189

Li YY, Xiao JH, Wu JJ, Duan JL, Liu Y, Ye XG, Zhang X, Guo XP, Gu YQ, Zhang LC, Jia JZ, Kong XY (2012) A tandem segmental duplication (TSD) in green revolution gene Rht-D16 region underlies plant height variation. New Phytol 196:282-291

Lin ZS, Zhang ZY, Xin ZY, Ma YZ, Kong FJ, Li LC, Wang XP (2002) Identification of ditelosome 7Ai-1 $\mathrm{L}$ of the chromosome arm in Thinopyrum intermedium by cytogenetic methods and its microdissection and microcloning. Sci Agri Sin 35:1049-1054 (in Chinese with English abstract)

Liu BH, Deng JY (1986a) A dominant gene for male sterility in wheat. Plant Breed 97:204-209

Liu BH, Deng JY (1986b) Genome study and telosomic analysis of the single dominant male-sterile Tal gene in common wheat. Science in China (Ser B) 29(5):516-526 (in Chinese with English abstract)

Liu BH, Yang L (1991) Breeding of dwarfing-sterile wheat and its potential values in wheat breeding. Chin Sci Bull 36(18):1562-1564 (in Chinese with English abstract)

Liu BH, Yang L, Wang SH, Meng FH (2002) The method and technique of population improvement using dwarf male-sterile wheat. Acta Agron Sin 28(1):69-71 (in Chinese with English abstract)

Maan SS, Carlson KM, Williams ND, Yang T (1987) Chromosome arm location and gene centromere distance of a dominant gene for male sterility in wheat. Crop Sci 27(3):494-500

Mahanil S, Reisch Bl, Owens CL, Thipyapong P, Laosuwan P (2007) Resistance gene analogs from Vitis cinerea, Vitis rupestris, and Vitis hybrid Horizon. Am J Enol Vitic 58(4):484-493

Murashige T, Skoog F (1962) A revised medium for rapid growth and bioassays for tobacco cultures. Physiol Plant 15:473-497

Qi LL, Gill BS (2001) High-density physical maps reveal that the dominant male-sterile gene Ms 3 is located in a genomic region of low recombination in wheat and is not amenable to map-based cloning. Theor Appl Genet 103(6-7):998-1006

Shatskaya OA, Zabirova ER, Shcherbak VS, Chumak MV (1994) Mass induction of maternal haploids in corn. Maize Genet Coop Newslett 68:51

Shewry PR (2009) Wheat. J Exp Bot 60(6):1537-1553

Suenaga K, Nakajima K (1989) Efficient production of haploid wheat (Triticum aestivum) through crosses between Japanese wheat and maize (Zea mays). Plant Cell Pep 8(5):263-266

Sun JS, Liu H, Lu TG, Wang XA, Ren Z, Wang JL, Fang R, Yang C (1992) The production of haploid wheat plants via wheat $\times$ maize hybridization. Acta Bot Sin 34:817-821 (in Chinese with English abstract)

Sun JS, Lu TG, Xin HW (1999) Obtaining homozygote of Taigu genic male-sterile wheat by chromosome elimination. Acta Bot Sin 41(3):254-257 (in Chinese) 
Tester M, Langridge $P$ (2010) Breeding technologies to increase crop production in a changing world. Science 327(5967):818-822

von Well E, Ncala M (2013) The role of the germplasm bank in cultivar development. Koringfokus Wheat Focus 9-10:36-37

Wang GJ (1998) Study on the production frequency of haploid plants in the cross of wheat and maize. J Triticeae Crops 18(6):12-14 (in Chinese with English abstract)

Wang P, Chen YR, Fang R, Wu LP, Zhu ZQ (1989) Study of identification of ploidy in pollen plants and wheat using guard cells. Acta Agri Uni Pekinensis 15:141-145, in Chinese (in Chinese with English abstract)

Zhai HQ, Liu BH (2009) The innovation of dwarf male sterile wheat and its application in wheat breeding. Sci Agric Sin 42(12):4127-4131 (in Chinese with English abstract)

Zhang ZL, Qiu FZ, Liu YZ, Ma KJ, Li ZY, Xu SZ (2008) Chromosome elimination and in vivo haploid production induced by Stock 6-derived inducer line in maize (Zea mays L.). Plant Cell Rep 27:1851-1860

doi:10.1186/1999-3110-55-26

Cite this article as: Zhang et al:: Production and identification of haploid dwarf male sterile wheat plants induced by corn inducer. Botanical Studies 2014 55:26.

\section{Submit your manuscript to a SpringerOpen ${ }^{\circ}$ journal and benefit from:}

- Convenient online submission

- Rigorous peer review

- Immediate publication on acceptance

- Open access: articles freely available online

- High visibility within the field

- Retaining the copyright to your article

Submit your next manuscript at springeropen.com 